\title{
The substance of citizenship: is it rights all the way down?*
}

\author{
Chiara Raucea
}

\section{Introduction}

Citizenship status is what traditionally expresses full membership within a political community. ${ }^{1}$ Formal political membership is also what traditionally gives access to a full range of legal entitlements that, bundled together, fall under the name of 'citizenship.' ${ }^{2}$ Therefore, citizenship status conveys both the idea that someone is part of a specific political community, and the idea that someone is entitled to take part in the equal distribution of social goods occurring within this political community. ${ }^{3}$ However, can formal political membership adequately register all those who are actually involved in the practices of creation and exchange of social goods that hold a political community together? And so, can formal political membership be an adequate hallmark, which lets us know who is to be

* I am grateful to the members of the Tilburg Legal Philosophy Research Group for their comments and critical remarks on earlier drafts of this article.. Many thanks also to the two anonymous reviewers of this journal, and to the editors Elaine Mak and Lukas van den Berge.

1 See, e.g., John G.A. Pocock, 'The Ideal of Citizenship Since Classical Times,' Queen's Quarterly 99 (1) (1992): 35-55. Richard Bellamy, Citizenship: A Very Short Introduction (Oxford: Oxford University Press, 2008), 18-33.

2 Around the early 1990s, research on citizenship has gained momentum, see, e.g., Will Kymlicka and Wayne Norman, 'Return of the Citizen: A Survey of Recent Work on Citizenship Theory,' Ethics 104 (2) (1994): 352-81. For a comprehensive overview on the main contemporary debate on citizenship rights and political membership, see, e.g., the collections of essays on the topic: Ronald Beiner, ed., Theorizing Citizenship (Albany: State University of New York Press, 1995), 1-20; Engin F. Isin and Bryan S. Turner, eds., Handbook of Citizenship Studies (London: Sage, 2002), 1-9; Richard Bellamy and Antonino Palumbo, eds., Citizenship (Farnham, UK, and Burlington, VT: Ashgate, 2010).

3 The academic literature on citizenship and political community has revealed the emergence of several contrasting themes, especially as regards the interplay between individual rights and common good. There are mainly two takes on this interplay confronting each other: the liberal and the communitarian approach to citizenship. The liberal view gives a prominent place to individual rights: Equal access to citizenship rights allows free and equal citizens to pursue their own conceptions of good and promote their own self-interest, within the constraints dictated by the respect due to the rights of others. See John Rawls, A Theory of Justice, rev. ed. (Cambridge, MA: Harvard University Press, 1999), 54. As opposed to the liberal understanding of individuals as independent and 'encumbered' selves, the communitarian view gives instead a prominent role to the notion of common good and emphasizes the political participation of individuals and their contributions to the life of the political community. See Michael J. Sandel, Democracy's Discontent: America in Search of a Public Philosophy (Cambridge, MA: Harvard University Press, 1998), 13-19. A significant analysis of strengths and limitations of both the liberal and the communitarian approach to citizenship is provided in Chantal Mouffe, 'Democratic Citizenship and the Political Community,' in Community at Loose Ends, ed. Miami Theory Collective (Minneapolis: University of Minnesota Press, 1991), 70-82. 
considered part of a political community? The present paper aims to address these two questions.

To this end, the study focuses on the limits of formal political membership in reference to distributive issues. The analysis targets EU citizenship ${ }^{4}$ and, more specifically, threshold cases, in which members and non-members are entangled in such a way that decisions concerning the rights of non-members unavoidably have an impact on members' opportunity to enjoy their citizenship rights.

The starting point of our enquiry is a judgement from the Court of Justice of the European Union (CJEU), which concerns both the rights of European citizens and the rights of third country nationals (TCNs). In 2011, the CJEU was asked whether European citizenship held by a minor, who is dependent on a TCN parent, can be invoked to grant the TCN parent a derived right to reside in the territory of the Union (Ruiz Zambrano case ${ }^{5}$ ). The CJEU replied affirmatively: a right of residence and a work permit cannot be refused to a third country national who is a family member of a European citizen, when such refusal would deprive the latter of the 'genuine enjoyment of the substance of the rights attaching to the status of European Union citizen.'

In this judgement, the reference to the 'substance' of citizenship rights works as common ground to grant protection both to EU citizens (and so, formal members) and to a special category of third country nationals (non-members). Thanks to this reference to the substance of citizenship rights, the Court connects the right to reside of EU minor citizens with the derived right to reside of their primary carers. The derived rights of TCN parents are protected insofar as the permanence of the parents in the territory of the Union practically prevents the expulsion of EU minors.

Since Zambrano, the formula referring to the substance of rights has been systematically used in a new trend of European citizenship cases ${ }^{7}$ to set the conditions

4 On EU citizenship as both a distinctive legal status and a political ideal, see Jo Shaw, 'Citizenship: Contrasting Dynamics at the Interface of Integration and Constitutionalism,' in The Evolution of EU Law, eds. Paul Craig and Gráinne de Bùrca (Oxford: Oxford University Press, 2011), 575.

5 Case C-34/09, Gerardo Ruiz Zambrano v. Office national de l'emploi (ONEm), ECLI:EU:C:2011:124.

6 Zambrano, para 42

7 Case C-434/09, Shirley McCarthy v. Secretary of State for the Home Department, ECLI:EU:C: 2011:277. Case C-256/11, Murat Dereci \& Others v. Bundesministerium für Inneres, ECLI:EU:C: 2011:734. Case C-40/11, Yoshikazu Iida v. Stadt Ulm, ECLI:EU:C:2012:691. Joined cases C-356/11 and C-357/11, O., S. v. Maahanmuuttovirasto \& Maahanmuuttovirasto v. L., ECLI:EU:C:2012:776. Case C-87/12, Ymeraga v. Ministre du Travail, de l'Emploi et de l'Immigration, ECLI:EU:C:2013:291. Case C-86/12, Jarel Moudoulou, Eja Moudoulou v. Ministre du Travail, de l'Emploi et de l'Immigration, ECLI:EU:C:2013:645. Case C-165/14 Alfredo Rendón Marín v. Administración del Estado, ECLI:EU:C:2016:675. Case C-304/14 Secretary of State for the Home Department v. CS, ECLI:EU:C: 2016:674. Case C 115/15, Secretary of State for the Home Department v. NA, ECLI:EU:C:2016:487. At the time of writing, the development concerning this body of case law is still on-going and the latest judgement on the matter was delivered by Grand Chamber on May 10th, 17: Case C-133/15, H.C. Chavez-Vilchez and Others v. Raad van bestuur van de Sociale verzekeringsbank and Others, ECLI:EU:C:2017:354. 
under which TCNs can, or cannot, derive rights from Union citizenship. So, rather than being just about the fate of Union citizens, this formula has turned to be mainly about decisions concerning categories of individuals that ought to be included within the protective scope of European citizenship, notwithstanding the lack of the formal status of 'Citizen of the Union.' For this reason I will argue that the reference to the substance of citizenship rights, in the context of EU citizenship cases, has the full, but still concealed, potential to shape the membership structure of the European political community.

\section{Part 1 Three hypotheses on the substance of citizenship rights}

\subsection{The Zambrano formula: substance as a mode of enjoyment of rights}

'The genuine enjoyment of the substance of the rights attaching to the status of European Union citizen' is quite a mouthful. But, actually, the formula launched in Zambrano has a very basic and practical purpose. It provides national courts with a guiding example about what kind of protection individuals can derive from EU citizenship. The seventeen words of the Zambrano formula refer to two essential prohibitions: ${ }^{8}$ (1) EU citizens shall not be expelled from the territory of the European Union; (2) EU citizens shall not be affected, directly or indirectly, by decisions made by national authorities that, for those citizens, would amount to a de facto expulsion from the territory of the Union.

The first prohibition revolves around a specific right: the right to reside. According to EU law, EU citizens have a right to reside in the territory of the Union. This right is additional to the protection that EU citizens can derive from their national citizenship against the risk of expulsion from the territory of their Member State of origin. The second prohibition is less straightforward: the number of citizenship rights that can be counted within its protective scope is indefinite. The Court does not provide a closed list of EU citizenship rights. It opts instead for the formula referring to the substance of citizenship rights to safeguard a mode of enjoying rights that is defined as 'genuine. ${ }^{9}$ A complete list of European citizenship rights - if practically possible at all - would still not shield EU citizens from the risk of being subjected to forms of de facto expulsion from the territory of the Union. De facto expulsions happen in all cases where national authorities can interfere with the enjoyment of the rights of EU citizens without taking decisions that are personally directed at them. On the backside of individual citizenship rights, there are in fact family ties and social bonds that sustain the enjoyment of such rights; ${ }^{10}$ once this background of social ties is damaged by decisions

8 The Court of Justice clarified the meaning of the Zambrano formula in a later case: Dereci, para 40.

9 See also Loïc Azoulai, Ségolène Barbou des Places, and Etienne Pataut, 'Being a Person in the European Union,' in Constructing the Person in EU Law, ed. Loïc Azoulai, Ségolène Barbou des Places, and Etienne Pataut (Oxford and Portland, OR: Hart Publishing, 2016), 10.

See also Bellamy, Citizenship, 26-27. 
of national authorities, the very enjoyment of individual citizenship rights is negatively affected. The Zambrano formula takes into consideration such danger.

That is why, despite of its complex structure, there is a simple idea underpinning the Zambrano formula: citizenship is not about protecting scattered individual interests, but it is about protecting interconnected rights of individuals who share a common place, which in this case is the territory of the Union. An attentive reader will notice that, in the Zambrano formula, rights are described as attach-ing rather than as being attach-ed to the status of European Union citizens. While a past participle (such as attach-ed) would signal a process that has already come to an end, whose effects are for the most part crystallized, the use of a present participle (attach-ing) signals, instead, that a process is still going on. ${ }^{11}$ The -ing ending, in this case, can be considered as an indicator of the continuous nature of the process through which citizenship rights emerge as interconnected parts of one of a kind. Each citizenship right is responsible for the actualization of the enjoyment of other rights, and all rights together bring to existence a meaningful link between rights and status. For example, the possibility to earn a living is connected with the possibility of exercising free movement rights; the right to stay in a territory is connected with the possibility to enjoy protection for family life in this territory, and so on. Moreover, the links between rights go beyond the situation of a single rightsholder. ${ }^{12}$ And so, certain categories of TCNs get into the protective orbit of EU citizenship, because it is not possible to exclude them from the enjoyment of rights, which are traditionally reserved to EU citizens, without at the same time excluding their minor children, who are formally citizens of the Union.

The notion of citizenship that comes out of the Zambrano formula is then one that brings to the fore the intersubjective and relational nature of citizenship rights. The reference to the substance secures the actualization of citizenship rights through the maintenance and protection of certain social bonds. In doing so, the reference to substance acknowledges and bolsters up a strong functional link between two issues that have frequently been addressed as two distinct problems in citizenship theory: namely, access to political membership and participation in socio-economic practices of creation and exchange of social goods. ${ }^{13}$

Even though, nowadays, the word 'substance' is widely used in ordinary language, the term is a philosophical one at root. So, why did the Court resort to a term with such heavy philosophical heritage? Was this choice just a rhetorical move? In the sections that follow, I will explain how the concept of the substance of rights can be of use to philosophical enquiries about citizenship.

11 Michiel van Lambalgen and Fritz Hamm, The Proper Treatment of Events: Explorations in Semantics (Oxford: Blackwell Publishing, 2005), 46.

12 See Azoulai, Barbou des Places, and Pataut, 'Being a Person in the European Union,' 3-9.

13 See, e.g., Michael Walzer, 'The Civil Society Argument,' in Beiner, Theorizing Citizenship, 153-74. 


\subsection{Substance as substratum: Walzer and the problem of infinite regress}

According to a traditional reading, the process of settling the membership question (who are the members?) and the process of settling the distribution question (what rights? and how to distribute these rights?) involves a sequence. ${ }^{14}$ For example, in the account of membership provided by Michael Walzer in his book Sphere of Justice, ${ }^{15}$ this temporal sequence is articulated as entailing a conceptual necessity to grant priority to the membership question. Walzer insists that all distributive choices within a political community require a previous act of closure of the community. ${ }^{16}$ However, if we try to read the Zambrano judgement through the lens of the Walzerian model, we run into difficulties, since, in this case, the distribution question concerning formal members cannot really be solved without involving non-formal members in the distribution of social goods.

At the beginning of his chapter devoted to membership, Walzer explains how his model is based on a fixed sequence, whereby political membership must precede decisions on distribution. ${ }^{17}$ And still this account cannot escape the fact that the process of looking backwards and making decisions on distribution dependent on previous decisions on political membership does not explain how political communities happen to be bounded in the first place. To use Walzer's own words, a political community is 'a group of people committed to dividing, exchanging and sharing social goods first of all among themselves.' But, how does this commitment behind distribution arise?

This question hints at a weak point in the argument proposed by Walzer: the problem of infinite regress. ${ }^{18}$ In other words, Walzer explains that decisions about distribution are grounded on decisions about membership. But, again, decisions about membership stand just as much in need of an explanation as the original distribution pattern that was to be explained. Membership boundaries appear, then, as a sort of ungrounded ground. ${ }^{19}$ This sort of conundrum is not new in the philosophical debate concerning the doctrine of substance.

14 On the topic of 'special rights' and 'bounded communities,' see also Rainer Bauböck, Transnational Citizenship: Membership and Rights in International Migration (Aldershot, UK; Brookfield, VT: Edward Elgar Publishing, 1994), 232-48.

15 Michael Walzer, Spheres of Justice (New York: Basic Books, 1983).

16 Walzer, Spheres of Justice, 22.

17 Walzer, Spheres of Justice, 22.

18 Carens argues similarly to my objection to Walzer's account of ungrounded membership boundaries with regard both to Nozick's justification for state's prerogative to restrict immigration, and to Rawls's assumption about a closed system in which questions about immigration could not arise. However, Carens reaches a different conclusion by proposing to assume a global view on the Rawlsian original position. See Joseph H. Carens, 'Aliens and Citizens: The Case for Open Borders,' in Beiner, Theorizing Citizenship, 229-53.

19 A critical enquiry into the normative foundations of the distinction between 'members' and 'nonmembers' is provided also in David Miller, 'Immigrants, Nations, \& Citizenship,' Journal of Political Philosophy 16 (4) (2008): 371-90. 
In his tract An Essay Concerning Human Understanding, ${ }^{20}$ Locke tells the story of the Indian philosopher who maintains that the world rests on an elephant; which, in its turn, rests on a tortoise. Locke provocatively adds that being familiar with the concept of substance would have spared the naïve philosopher the trouble of assuming that an elephant on top of a tortoise bears the weight of the earth! ${ }^{21}$ In Locke's view, the Indian philosopher is not the only one to blame for his naïveté: He might have taken as satisfactory the story that the world rests on something that he does not know, but so too have many European philosophers throughout the centuries. As Locke remarks: 'Substance without knowing what it is, is that which supports Accidents. So that of Substance, we have no Idea of what it is, but only a confused obscure one of what it does.'22

In the Lockean story, the naïve philosopher resorts to substance as a way to silence questions he is not capable of answering. With regards to citizenship, there is no shortage of troublesome questions. The very basic tenet that a citizen is a member of a political community, who enjoys the rights and assumes the duties of membership, is already loaded with questionable premises. According to this basic tenet, political membership is the access point to the enjoyment of citizenship rights. But, if this is the case, and so if political membership is a sort of meta-right that provides the necessary standing to claim citizenship rights, then is there also a right to be counted as a member within a political community? And, on what grounds does this political status, or 'right to have rights' (to use

20 John Locke, An Essay Concerning Human Understanding, ed. Peter H. Nidditch (Oxford: Oxford University Press, 2011). Essay II, xii.

21 According to a traditional interpretation, Locke does not entirely reject the notion of 'substance as substratum' as formulated in the scholastic tradition, despite of the fact that he was sceptically depicting such account in his ironic fable of the Indian Philosopher. See, e.g., Edwin McCann, 'Locke on Substance,' in The Cambridge Companion to Locke's 'Essay Concerning Human Understanding,' ed. Lex Newman (Cambridge: Cambridge University Press, 2007), 157-91. McCann argues that interpreting Locke's theory of substance in line with a notion of substance as substratum 'It's a traditional interpretation in two senses: first, it locates Locke's idea of substance within the tradition of Aristotelian logic, broadly construed; and second, it was the most widely accepted interpretation of Locke's doctrine of substance among Locke's contemporaries and critics, and it was a standard view among commentators, down to about thirty years ago' (McCann, 'Locke on Substance,' 161). In recent years, however, this traditional interpretation of Locke's theory of substance has fallen out of favour, see McCann, 'Locke on Substance,' 163-85. Among the recent rival interpretations to the traditional interpretation of Locke's theory of substance, in this paper, I will follow the interpretation provided by Jonathan Bennett in his article titled 'Substratum' (1987), see McCann, 'Locke on Substance,' 174-77 and Jonathan Bennett, 'Substratum,' History of Philosophy Quarterly 4 (2) (1987): 197-215. There are three main reasons why I choose to follow Bennett's interpretation of Locke's substance theory. Firstly, Bennett puts great emphasis on Locke's ambivalent attitude towards the notion of substance as substratum. The second reason is that I agree with Bennett's explanation of Locke's ambivalent attitude. That is, Locke acknowledges, on the one hand, the conceptual demand that there is a support to qualities but, on the other hand, is committed to an empiricist theory of meaning and according to this theory the substratum can only be unknowable since it is not directly availably to sensory observation. The third reason is that I concur with Bennett about the idea that Locke's idea of substance is to be reconnected with Locke's interest in our conceptual structure and in their expression in language. See Bennett, 'Substratum,' 207, 211-12. 
the well-known phrase coined by Arendt) ${ }^{23}$ stand on? Is it rights all the way down?

In my view, there is a way out of this problem of infinite regress, and that is to avoid looking at membership within a political community as the most basic right on which other citizenship rights stand on. I suggest focusing instead on the functional relation between membership boundaries and equal distribution. When Locke introduced his fable, he presented the problem of arranging human knowledge as a frame of reference for his criticism. ${ }^{24}$ Locke's criticism is directed towards an account of substance that makes use of this concept with a view to introduce a substratum (support) to which properties (or accidents, to use Locke's terminology) are attached.

If we go back to the Ruiz Zambrano formula, we notice that the Court of Justice is also dealing with a problem of arranging legal knowledge with the purpose of making distinctions between rights that can be protected by invoking EU citizenship, and rights that cannot. However, the reference made by the Court of Justice to the substance of citizenship rights is able to deflect the kind of criticism made by Locke, because, in the Zambrano formula, substance does not stand for a metaright to be interpreted as a support to which citizenship rights are attached. Contrastingly, as we have seen in the previous section, the reference to substance in the Zambrano formula is useful for zooming in on the connections between rights and on the practical conditions that lead to a genuine enjoyment of EU citizenship. The Court does not confine itself to only assessing the claims of those individuals who formally possess the status of citizen of the Union. Instead, the Court of Justice brings to the fore a dimension of citizenship that usually remains latent. That is the relational and intersubjective dimension of citizenship, which allows the Court to consider each citizenship right as a parcel of a more complex pattern of distribution of social goods and to take into account how the enjoyment of a single right depends on the actual practices of participants in such distribution. Decisions on the enjoyment of rights and decisions on membership boundaries are, then, entangled.

This view contrasts with accounts of citizenship, such as the one proposed by Walzer, that present the act of the self-closure of political communities as an historical event, which is not encompassed in a theory of distributive justice. ${ }^{25}$ Walzer's choice of relegating decisions on membership to a distant past has the effect of excluding such decisions from the domain of the political in the present, ${ }^{26}$ and works as a limit to the set of decision-making options that can be available for a political community. Moreover, in Walzer's view, this process of crystallization does not involve membership alone. There is 'a before and after' also with

23 Hannah Arendt, The Origins of Totalitarianism (San Diego, CA: Harcourt Brace Jovanovich, 1973).

24 See Bennett, 'Substratum,' 207, 211-14.

25 Walzer, Spheres of Justice, 32. See also Carens, Aliens and Citizens, 244.

26 Hans Lindahl, 'Breaking Promises to Keep Them: Immigration and the Boundaries of Distributive Justice,' in A Right to Inclusion and Exclusion? Normative Fault Lines of the EU's Area of Freedom, Security and Justice, ed. Hans Lindahl (Oxford: Hart Publishing, 2009), 137-59, esp. 140. 
regard to the process of creating the social meaning of what counts 'as a good' in the distribution of social goods:

People conceive and create goods, which they then distribute among themselves. Here, the conception and creation precede and control the distribution. (...) goods come into people's mind before they come into their hands. ${ }^{27}$

Meaning is attach-ed to goods before a community can decide how to distribute them. So, as in the case of membership, Walzer considers the domain of the attribution of meaning to social goods as being outside of the scope of distributive justice. The shortcoming of such a model of distribution is that it does not account for the fact that the process of attribution of meaning to social goods takes place in a flux of continuous change. In this regard, the focus of the Zambrano formula on the rights attach-ing to the status signals that the process of defining the meaning of citizenship in terms of rights has not yet come to an end. The process of sorting out what counts as a citizenship right and what does not, is an ongoing process, which happens simultaneously alongside the process of distributing rights. 'What shall count as a citizenship right?' and 'Who shall not be excluded from the distribution of citizenship rights?' are political questions that need to be settled, re-opened and then resettled over time. Through adjudication on citizenship rights, courts contribute to the continuation of this process. Once we acknowledge that adjudication on citizenship rights needs to be attuned to the intersubjective dimension of rights, we then need to acknowledge that the relation between status and rights is permanently in the making. Therefore, accounts - like the one proposed by Walzer - that crystalize the relation between decisions on membership and decisions on distribution into a fixed sequence are to be revised.

\subsection{Substance as essence: Benhabib and the problem of boundaries}

Differing from Walzer, who frames the problem of political membership in relation to the problem of the distribution of social goods, Seyla Benhabib frames the problem of political membership as a matter of classification: a question of 'sorting,' to borrow an expression used by Locke. ${ }^{28}$ At the very beginning of The Rights of Others, Benhabib explicitly presents her approach to the problem of political membership by stating that:

By political membership, I mean the principles and practices for incorporating aliens and strangers, immigrants and newcomers, refugees and asylum seekers, into existing polities. Political boundaries define some as members, others as aliens. Membership, in turn, is meaningful only when accompanied by rituals of entry, access, belonging, and privilege. ${ }^{29}$

29 Seyla Benhabib, The Rights of Others: Aliens, Residents, and Citizens (Cambridge: Cambridge University Press, 2004), 1. 
This quotation clearly shows how Benhabib opts to focus on the exclusionary function of political membership, rather than on its distributive function. In her account, the function of defining some individuals as members and others as aliens prevails over the function of 'making' the members equally entitled to distribution, to which Walzer gave priority. ${ }^{30}$ She zooms in on the dividing line that sets the members of a constituted and closed 'We' apart from the 'Others' who demand admittance and inclusion. The goal of her enquiry is to discover the grounds from which such a dividing line can be challenged, and to find out how a just membership can be obtained. ${ }^{31}$ In her conclusions, she advocates for porous membership boundaries, arguing that membership boundaries can be challenged by appealing to universalist claims based on the human rights regime. ${ }^{32}$

Walzer and Benhabib hold profoundly different understandings of the problem of political membership in relation to distributive concerns. That is because the two authors present their views on distribution from two diverse standpoints. Walzer's model is based on a standpoint that coincides with the one of the formal members of a particular political community. The standpoint from which Benhabib's critique of membership boundaries departs is instead one that transcends particular political communities and their specific internal distributive purposes. To introduce such transcendental standpoint, Benhabib explains how, in modern democracies, individuals have a 'dual, fractured identity': they are bearers of citizenship rights by virtue of being members of a political community but, at the same time, they are bearers of human rights qua moral persons. ${ }^{33}$ These two positions can be played against each other: Someone who is not in the position to claim rights qua member of a political community, can still claim to be a bearer of human rights qua moral person. And this argument can be used to challenge, from the outside, the way in which the distinction between members and nonmembers has been drawn by the members of a political community. ${ }^{34}$

In Benhabib's account, the claims to distribution of social goods have a context transcending validity ${ }^{35}$ and, therefore, can be assessed from a universal standpoint, which must trump the insider-standpoint of members. ${ }^{36}$ However, the argument proposed by Benhabib cloaks a basic problem. It assumes that there can be a unifying standpoint on distribution that transcends the diverse particular

30 Benhabib, The Rights of Others, 3.

31 A similar undertaking is carried out, and a similar call for universal principles is offered in Carens, Aliens and Citizens, 248.

32 Carens, Aliens and Citizens, 22.

33 Carens, Aliens and Citizens, 123.

34 See also Seyla Benhabib, 'In Defense of Universalism - Yet Again! A Response to Critics of Situating the Self,' New German Critique 62 (2004): 173-89, esp. 188.

35 Benhabib, 'In Defense of Universalism - Yet Again!', 178. For a critical response to Benhabib's argument on the context-transcending force of certain normative claims, see Nancy Fraser, 'False Antitheses: A Response to Seyla Benhabib and Judith Butler,' in Der Streit um Differenz, ed. Seyla Benhabib (Frankfurt: Fischer, 1993), 64-65. 
communities and that is not dependent on their specific distributive practices. But what are the foundations for such a universal standpoint on distribution?

Benhabib's account is at odds with the idea that each political community exists and maintains itself by virtue of an act of self-closure, and by means of practices of distribution of social goods that occur among and on behalf of its members. Differently from Walzer - who justifies the internal standpoint held by the members of a particular political community on the ground of their engagement in a common distributive enterprise (an enterprise that requires a closure of the circle of participants and beneficiaries) - there is no common distributive enterprise underpinning the universal standpoint evoked by Benhabib. Instead, it is an appeal to a shared humanity that underpins the universal standpoint on which Benhabib bases her vindication of ' $[\mathrm{t}]$ he right of every human being "to have rights", that is, to be a legal person, entitled to certain inalienable rights, regardless of the status of their political membership.'37

In what follows I will acknowledge that Benhabib provides good reasons to reject an entirely unrestricted process of self-closure of political communities. But I will also explain why opting for a transcendental and universal standpoint - as Benhabib does - is not a workable solution either. A universal standpoint on membership boundaries merely shifts the problem from one status (the one of 'member' of a political community) to another (the one of 'human being'). Moreover, such a shift dissolves the functional link that connects the emergence of an equal status and the possibility of ordering the practices of distribution of social goods according to the principle of equality.

\subsection{Naming, sorting, distributing: three examples of unrestrictable collective enterprises}

As we have seen, Benhabib frames the problem of political membership as a matter of sorting individuals into the categories of 'members' and 'aliens.' This frame depends on two of Benhabib's choices: the choice of a universal point of view on membership boundaries, and the choice of leaving distributive concerns aside. Two particularly troublesome consequences may arise from these choices.

The first consequence is that the focus of the enquiry on political membership shifts from distribution to identity. ${ }^{38}$ The very classification becomes the bone of contention, while the issue of 'what this classification is for?' fades into the background. ${ }^{39}$ This shift from distribution to identity is evident in those passages of The Rights of Others where Benhabib presents her own reading of Walzer's account of communal self-determination. ${ }^{40}$ Whereas in the Walzerian account the community's understanding of itself pertains both to the sphere of collective identity and to the sphere of distribution, in Benhabib's reading, all of the atten- 
tion is focused on identity. The result is, then, an impoverishment of the concept of the community's understanding of itself. In Benhabib's view, the 'We' invoked by Walzer suggests 'an identity without conflict, a unity without fissure. ${ }^{41}$ If on the one hand, Benhabib expresses understandable concerns about the political consequences that may be produced by the fiction of a homogenising 'We' that is deprived of internal conflict; on the other hand, her concern about such homogenising effect is mostly due to her own choice of leaving distributive concerns outside of the picture. As long as we stick with Walzer's original premise that the self-closure of a political community is functional to the distribution of social goods, it is possible to detect an internal tension in the Walzerian account. This is the tension that I will explore at length in Part 2: the tension that originates from the mismatch between the circle of formal members and the pool of the actual participants in the practices of exchange of social goods, which hold a political community together.

The second troublesome consequence deriving from Benhabib's choice of assessing membership boundaries from a transcendental and universal point of view is her reference to a "human right to have rights. ${ }^{42}$ She indeed designates universalist rights as core rights to which all individuals shall be entitled, by virtue of their humanity alone. Universal moral claims are presented as the hard-core of citizenship across different political communities, and they must play the role of constraints upon the insider-standpoint of members for what concerns decisions about membership boundaries and the distribution of citizenship rights. ${ }^{43}$

Such an approach has its own drawbacks and, once again, Locke's criticism of the use of the substance doctrine in philosophic enquires might help us to deal with them. More specifically, in Book III of the Essay Concerning Human Understanding, ${ }^{44}$ Locke discusses the distinction between real and nominal essence ${ }^{45}$ and introduces two different problems about knowledge.

With respect to real essence, Locke refers back to the Aristotelian tradition of interpreting essence as 'The Core': the internal principle of any particular thing. ${ }^{46}$ The first epistemic problem concerning such a notion is that Essence is what remains 'unknown,' whereas human knowledge only has access to 'discoverable qualities.' Secondly, Locke contrasts real essence with nominal essence and argues that, due to scholastic interpretation, the term 'essence' has lost its original meaning and, instead, is currently used in the process of sorting things. From the definition of nominal essence, ${ }^{47}$ a second epistemic problem emerges: how is human knowledge arranged? According to Locke, one of the building blocks of

41 Benhabib, The Rights of Others, 120.

42 Benhabib, The Rights of Others, 43.

43 Benhabib, The Rights of Others, 135.

44 Margaret Atherton, 'Locke on Essence and Classification,' in Newman, The Cambridge Companion to Locke's Essay Concerning Human Understanding, 258-85.

45 Locke, Essay III, iii, 15.

46 Atherton, Locke on Essence, 259.

47 Locke, Essay III, iii, 15. See also, Bennett, 'Substratum,' 211-12. 
human knowledge is the process of grouping things into sorts according to the properties they 'appear' to share, so that every bundle of similar and constant properties goes under a specific name. Nominal essence is, then, the abstract idea by means of which we delineate the boundaries of each sort, and refers to those properties that a thing must have because of the kind of thing it is. ${ }^{48}$

From Locke, we can draw two main considerations: boundaries cannot be justified on the ground of their grip on reality; and boundaries need to be assessed as adequate, or indeed inadequate, only with regard to the epistemic function they perform. In light of such considerations, we can argue that Benhabib's choice of centring her account on universal moral claims may hide the two drawbacks against which Locke was warning his readers: the naturalist fallacy (even if in the end there is none $\left.{ }^{49}\right)$, and the problem of undecidable boundaries.

In regard to the naturalist fallacy, the first possible drawback of considering universal moral claims as core elements of citizenship across diverse political communities is, indeed, the view that rights claims are to be associated with physical and psychological attributes that necessarily pertain to human beings. This was the fallacy inherent in the doctrine of natural rights and rejected by Benhabib, who explicitly distances herself from naturalistic accounts. ${ }^{50}$ With such a disclaimer, Benhabib avoids being committed to an essentialist interpretation of citizenship. Her appeal to a shared humanity and her proposition of a human right to have rights are claims that are not grounded on an internal principle (real essence) that all humans naturally share by virtue of being humans. So, how are we to interpret Benhabib's appeal to a shared humanity and her proposition of a human right to have rights?

Benhabib finds a way out of the naturalistic fallacy by proposing a discourse-ethical justification of rights. ${ }^{51}$ But this shift presents a second possible drawback to her argument: the problem of what I call 'undecidable' boundaries. According to Benhabib, decisions about membership boundaries of political communities shall be in compliance with the principles of 'generality and reciprocity': ${ }^{52}$ despite of the fact that membership boundaries are drawn unilaterally by members, it is still possible to find common criteria to justify membership boundaries that are acceptable both for members and for non-members. But how can there be criteria that are 'good' for both members and non-members? And what would be the ultimate universal parameter to test whether the criteria chosen by members are indeed good criteria, rather than arbitrary criteria?

49 Benhabib articulates a post-metaphysical defence of moral and political universalism in Seyla Benhabib, Situating the Self (New York: Routledge, 1992). See also, Benhabib, 'In Defense of Universalism - Yet Again!', 174.

50 Benhabib, The Rights of Others, 129.

51 Benhabib, The Rights of Others, 129-43. In 'In Defense of Universalism - Yet Again!,' 175-76, Benhabib explains how her account differs from Habermas's version of the principle of universalizability.

52 Benhabib, The Rights of Others, 138. 
These questions echo Locke's concerns about disagreement and agreement on nominal essence. Boundaries that divide things into diverse sorts are, in Locke's view, the workmanship of human minds, ${ }^{53}$ and whilst they are made with some liberty, they are not made arbitrarily. ${ }^{54}$ However, whereas Benhabib talks about grounds of membership boundaries that are 'justifiable' both for members and for non-members, Locke insists that the boundaries drawn by human minds can be 'adequate' or 'inadequate. ${ }^{55} \mathrm{He}$ never engages in proving the justifiability of such boundaries with respect to a universal standpoint. I want now to draw attention on why the distinction between an 'adequate' and a 'justifiable' ground is of paramount importance, in particular for political boundaries.

In examining the situations in which the concept of nominal essence is a useful sorting device, Locke presents a short story illustrating the process of naming. ${ }^{56}$ What emerges from this story is that the question of whether a word is adequate or not to stand for a specific signification cannot be established in light of universal parameters, but only by considering the standpoint of the participants in the communicative practices. ${ }^{57}$

Comparably, when it comes to the act of setting the boundaries of a political community, the members (like the individual who invents a new word in Locke's story) are the ones who take the initiative to draw the dividing line between members and non-members. Members set membership boundaries because - as Walzer acknowledges - they are driven by the necessity to arrange their own distribution of social goods. At the end of the day, this is also a matter of organizing knowledge and producing shared meanings. They may have the liberty to set membership boundaries, but they have no special warrant to do so. The decisions about membership boundaries taken by members cannot be universally justifiable, since it does not make much sense to assess these decisions by transcending the distributive function they are meant to fulfil. This observation, however, does not mean that members can set their own membership boundaries at random. The dividing line between members and non-members needs to be adequate for the function for which it has been set into place: the distribution of social goods. It is therefore not only the formal members, but also all the participants in the practices of exchange of social goods that hold a political community together, that are the ones who can challenge or endorse the membership boundaries of a political community.

Every time we call into question membership boundaries from a standpoint that transcends the one that is necessarily entailed in the practices that have set those boundaries in place, the question of boundaries turns into an undecidable one. That is because there cannot be a parameter to assess boundaries, other than the 
one to assess their function in the context of a community of practices. A community of practices is, actually, necessary in Locke's parable about naming, in order to determine whether these new sounds introduced by an individual to denote an idea are widespread enough to be considered a new word. And a community of practices must also be the reference point to assess both membership boundaries and the decisions concerning distribution, over time.

The main legacy of Locke's criticism against the traditional doctrines of substance is that the arguments presented in his Essay shift the focus of the enquiry into 'substance.' With Locke, the focus moves from a level where substance was seen as something that is 'given,' towards a level where the enquiry into substance must come to terms with the ways in which human knowledge functions, as well as with its limits. Our enquiry into the substance of citizenship can benefit from a shifting of focus as well. In the context of citizenship, leaving aside a conception of substance as something that is 'given' entails leaving aside both those models that postulate the existence of given components of citizenship, and those other models that postulate the crystallization of the process through which human knowledge is arranged. For a political community, the process of specifying what the substance of citizenship consists of amounts to a process through which the political community has to make explicit what the pattern of distribution is. And this pattern has to be considered generally beneficial among all those who are part in it.

\section{Part 2 Citizenship and the process of self-definition of political communities}

\subsection{Re-reading the Walzerian account of political membership}

As we have seen in Part 1, the application of the Zambrano formula brings to light a complex problem: The foundations of distributive choices about citizenship rights. In a nutshell, this problem can be illustrated by what I call the citizenship grounding question $\left(\mathrm{C}^{\mathrm{Q}}\right)$ :

$\left[\mathrm{C}^{\mathrm{Q}}\right]$ What is it about citizenship that grounds both:

$\left(D^{Q}\right)$ the right to have a share in the distribution of social goods, and

$\left(\mathrm{M}^{\mathrm{Q}}\right)$ the capacity to claim that such share is equally due to those who have a place within the political community on whose behalf the distribution occurs? ${ }^{58}$

As this formulation shows, I argue that dealing with the $\mathrm{C}^{\mathrm{Q}}$ requires a twopronged approach. That is because citizenship is linked both to distribution of

58 In this formulation, the expression 'on whose behalf' is not yet disambiguated since the implications of its multiple meanings will be introduced at a later stage. 'On behalf of can have three possible meanings: 'in the name of,' 'in the interest of,' and 'on the part of, done by.' Oxford Dictionaries: http://www.oxforddictionaries.com/definition/english/behalf (accessed February 17, 2018). These three different meanings will become explicit once I introduce the two different groups of individuals (members and participants) that can be taken into account as reference points with respect to the $C^{Q}$. 
social goods (the Distribution Question: $\mathrm{D}^{\mathrm{Q}}$ ), and to equal political membership (the Membership Question: $\mathrm{M}^{\mathrm{Q}}$ ). And the function of citizenship is precisely to secure the convergence between decisions about distribution and decisions about political membership over time: equal shares are to be distributed by, and among, equal members.

By opting for a two-pronged approach, I can deal with the two sub-questions $\left(\mathrm{M}^{\mathrm{Q}}\right.$, $\mathrm{D}^{\mathrm{Q}}$ ) without presuming that the solution to one of them needs to predate the solution to the other. In this way, I can start my analysis without taking for granted the premises accepted by traditional accounts of citizenship, like the one provided by Walzer. In his honest analysis, Walzer reveals all the questions that his own model might leave unanswered. Taking my cue from those unanswered questions, I will propose my own answer to the $C^{\mathrm{Q}}$. Graphics will provide the readers with a handy support to visualize the differences between the account proposed by Walzer and mine.

\section{Walzer's account}

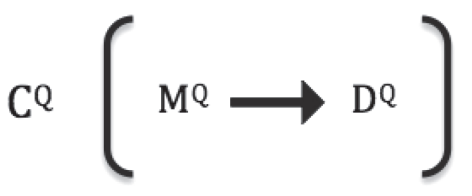

A unidirectional arrow going from the $\mathrm{M}^{\mathrm{Q}}$ to the $\mathrm{D}^{\mathrm{Q}}$ represents Walzer's main argument. As we have seen in Part 1, in his view, decisions on membership are constitutive of political communities: decisions on membership boundaries come first; patterns of distribution follow. ${ }^{59}$ In the graphic, the relation between the $\mathrm{M}^{\mathrm{Q}}$ and the $\mathrm{D}^{\mathrm{Q}}$ is given between brackets to represent how the Walzerian model leads to the effect of crystallizing the relation between membership boundaries and distribution. Membership boundaries unquestionably determine who has a right to have a share in the distribution of social goods on an equal basis. And only formal members will be in charge of changing membership structure over time. ${ }^{60}$ According to Walzer, the ground for decisions about membership is the collective right of a community to self-determination. ${ }^{61}$ This collective right is rooted in a particular vision of those people who are already part of the political community. ${ }^{62}$ And acts of demanding that come from the outside can influence but not radically transform the outcome of the reflexive process of self-understanding that a political community undergoes when it faces demands of admittance from outsiders. 
A palpable tension runs, however, through the whole chapter that Walzer devotes to the membership question in his Spheres of Justice. On the one hand, Walzer affirms that the collective right to self-determination allows members of the political community to take final and authoritative decisions about their own membership boundaries. On the other hand, he unfolds his analysis as if there also exists a principle that should work as a counterbalance to the collective right of self-determination. ${ }^{63}$ Unfortunately, Walzer never specified what this principle is and how it should work. ${ }^{64}$

There are two passages in which Walzer sketches the limits to the collective right of self-determination. The first concerns refugees' claims; ${ }^{65}$ the second one concerns the case of guest workers, long-term residents and second generation of foreigners who, despite their prolonged residence, and despite the fact that they have made a life in the territory of the host state, are denied access to citizenship. ${ }^{66}$ This second case is the more relevant for the purpose of our analysis, since it closely resembles the conditions of Mr Zambrano and other TCNs who have been able to invoke the 'substance of rights' formula. With regard to the situation of individuals who are able to enjoy long-term residence rights without access to full-blown citizenship, Walzer invokes political inclusiveness and claims that a host political community risks becoming a tyranny, unless political membership is 'offered' to individuals like guest workers. ${ }^{67}$ However, it is not clear how the political inclusiveness can limit the collective right to self-determination. The most obscure point is the reference that Walzer makes to membership held 'by right of place' and to the constraints that this right puts upon the naturalization process. This is the only occasion in Walzer's analysis where the right to membership seems determined by the physical presence of an individual in the territory of a political community, rather than by the collective decisions about membership criteria. ${ }^{68}$

In providing my own answer to the $C^{\mathrm{Q}}$, I target what I consider the two main blind spots in the Walzerian answer to this question $C^{\mathrm{Q}}$ : The static dividing-line between members and non-members, and the 'untameable' character of the collective right of self-determination. ${ }^{69}$ Both blind spots are, in my view, two sides of the same coin: they are the effects of reading the relationship between the $\mathrm{M}^{\mathrm{Q}}$ and the $\mathrm{D}^{\mathrm{Q}}$ as a sequential one. My account can be read, then, as a revised version of the Walzerian model whose novelty consists mainly in shifting the focus from

Walzer, Spheres of Justice, 60. See also, Carens, Aliens and Citizens, 248.

The second obscure point is the reference that Walzer makes to the moral principle of mutual aid, since Walzer himself, in another passage of the chapter (Walzer, Spheres of Justice, 48-51) writes that the collective right to self-determination trumps the principle of moral aid. Thus, it is not clear how a limit that can always be trespassed can still be considered as a true counterbalance.

69 Both these blind-spots were also highlighted by Benhabib, See Benhabib, The Rights of Others, 43. 
crystallized membership boundaries to the provisionality of the moment of selfclosure of a political community. The account I propose can be illustrated by the following graphic:

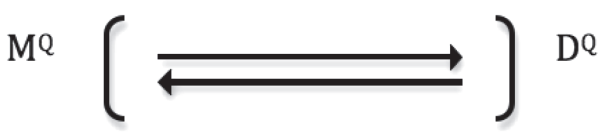

CQ

The two arrows represent my thesis that decisions about distribution are, together with decisions that set membership boundaries, co-constitutive of political communities. Visually, the graphic suggests that the question about the normative ground of citizenship leads to a point of undecidability: it is not possible to determine which decision comes first. The point of undecidability is reached because decisions about membership cannot be entirely self-standing; they are closely related to the practical functioning of the agreed pattern of distribution of social goods. The two opposing arrows in brackets point at a dynamic sense of temporality and signal that membership boundaries can never be fixed once and for all. The arrow from $\mathrm{M}^{\mathrm{Q}}$ to $\mathrm{D}^{\mathrm{Q}}$ signals that the self-closure of a political community is necessary in order to arrange distributive patterns of social goods. On the other hand, the arrow from $\mathrm{D}^{\mathrm{Q}}$ to $\mathrm{M}^{\mathrm{Q}}$ signals that self-closure needs to be provisional in order to allow for recursive adjustments that will tune the membership structure to the agreed pattern of distribution of social goods.

As we have seen in the last section of Part 1, and contrary to what Walzer suggests when he discusses the right to self-determination, there is no valid warrant that justifies, a priori, the act of self-closure of a political community. This means that the act of self-closure is not, in itself, a solid ground to justify final decisions about the exclusion of certain individuals from the agreed patterns of distribution of social goods. The act of self-closure can only be assessed in light of its function, which is the distribution of social goods according to the principle of equal shares. Therefore, the act of self-closure is not justified per se, but membership boundaries can still be considered necessary and adequate only as long as they allow for the keeping in place of a pattern of distribution of equal shares among the ones who take part in the life of the political community. In the next sections, I will come back to the reasons why a political community cannot escape the provisionality of its act of self-closure, and why its process of self-determination is driven by the necessity of re-adjustments.

\section{2 'We, the Members' and 'We, the Participants'}

The Walzerian model assumes that there is a correspondence between membership boundaries and the boundaries of the pool of participants who are involved in the distribution of social goods. However, the way in which the correspondence is posited is acceptable only as long as one assumes that those who do not hold formal political membership are also unquestionably excluded from access to the 
social goods exchanged and distributed within the bounded political community. There is an unavoidable danger in assuming such a static correspondence. ${ }^{70}$ This danger consists in the denial that forms of allocation of social goods are possible, and actually occur in political communities, even across the boundaries of political membership. Situations as the ones addressed by the Court of Justice with the application of the Zambrano formula actually suggest that even individuals who are not formal members can be inextricably embedded in the practices of creation and exchange of social goods that occur on behalf of a political community. There are other situations like Zambrano's one, such as the ones experienced by guest workers, second generation of foreigners and long-term residents, which Walzer himself discusses in his Sphere of Justice. The common feature of all these borderline cases is that the pool of individuals involved in sustaining the pattern of distribution of social goods to which a political community is committed is larger than the group of individuals who possess formal political membership. This means that, in all these borderline cases, the presupposed correspondence between those who actually take a share in the distribution of social goods and those who are formal members, breaks down. Zambrano parents, guest workers and the like represent cases of individuals who are not 'counted in' as formal members and nevertheless are 'taken in' by the political community through practices of distribution of social goods, capable of producing and keeping in place shared social meanings.

I qualify the admission of Zambrano parents and of other long-term residents as an act of 'taking-in' on purpose. The reason for such a qualification, is that their presence within the host political community is something more than a sporadic occurrence. Quite the opposite: their presence is needed for letting the pattern of distribution of social goods to which the host political community is committed work. Even though these individuals are not yet registered as formal members, they are no longer 'outsiders' since their presence is already tacitly registered in the pattern of exchange and distribution of social goods that is in place within the host community. This means that the existent pattern of exchange and distribution requires a sustained adaptation to the continuous presence and reiterated participation of the non-members in the life of the political community. And this sustained adaptation has the purpose of securing the survival of the political community and of bringing about the realisation of the distributive plan to which the political community is committed. For example, it is the commitment of the EU to respect the family and private life of EU citizens, together with the commitment to protect those citizens from expulsion, and with the commitment to grant them the right to freely move and reside in the territory of the Union, that underpin Mr Zambrano's derived right to live and work in the EU.

In light of these considerations, we can conclude that the act through which an individual takes a place within a political community is, actually, a fact that is not in the complete control of the political community. And it is a fact that eludes 
also the language of rights, claims and entitlements. This act of taking a place cannot be traced back to a prior legal entitlement to do so, but it works, on a later stage, as a background condition to claim the right to reside and to participate as equal in the communal life. Formal political membership actually presupposes a sense of collective purposiveness, which predates the counting of the members of a political community, and which introduces the necessity of boundary setting, but also of boundary adjustments. The possibility to adjust membership boundaries to distributive practices is the breaking point between my account and Walzer's model.

A rigid and unchallengeable membership structure could lead to a serious rupture of the correspondence between those who are formal members of a political community and those who already take part in the allocation of social goods that occurs within this political community. Once this rupture occurs, the very function of citizenship is at stake, since this rupture voids the original commitment made by the political community that makes citizenship meaningful. Namely, the commitment according to which the political community must engage in a distribution among equals. The correspondence between those who are part of the circle of distribution of social goods and those who are part of the circle of membership is endangered every time those individuals who are in borderline situations are forced to live as 'living-in foreigners, ${ }^{, 71}$ in a condition of permanent alienage.

In order to examine the reasons why re-adjustments on the membership structure of the hosting political community are needed in cases of failed correspondence, I would now like to draw attention to the fact that each occurrence of exchange of social goods, which is normatively ordered within a political community as a matter of distribution, is always ordered 'on behalf of this political community. Here, all three possible meanings of the expression 'on behalf of' are relevant. The distribution is, actually, 'done by' the participants in the practice of exchange of social goods; the distribution occurs 'in the interest of' all the participants and 'in their name.' That is precisely the condition that allows us to qualify the activity of ordering the practices of exchange of social goods within a political community as a process of distribution and self-ordering. The 'self' that works as a reference point in the process of self-ordering through which the distribution of social goods is regulated needs to be embedded in the very practices of creation and exchange of social goods that are regulated. To put it simply, the distribution of goods is regulated on behalf of the participants in the practices of creation and exchange of social goods when the participants are taking part in 'their own' distribution.

These considerations shed a new light on the borderline situations discussed by Walzer and on the cases decided thanks to the genuine enjoyment formula. In all of

71 I use the expression 'living-in foreigners' to recall to mind the similar expression which Walzer used ('living-in servants'). I opted for a slightly different variant because I want to put emphasis on the denial of equal membership, which affects individuals in borderline situations. It is precisely such denial that forces them into a subaltern position. 
these cases, there are individuals who are taking part in the distributive practices of a political community. However, what is contested in all these cases is whether or not these individuals are taking part in 'their own' distribution. According to the Walzerian model, they could not claim that the distribution in which they are taking part is occurring on their own behalf. This is because the distribution of social goods always happens 'on behalf of members' of a bounded political community.

However, Walzer himself presents the act of self-closure as an act driven by a precise necessity: A closed circle of participants is necessary to allow the distribution of equal shares of social goods. That means that the original function of the act of self-closure is the seizing of a correspondence between 'We, the Members of a political community' and 'We, the Participants in our own distribution.' I argue that the purpose of securing this correspondence between 'We, the Members' and 'We, the Participants' is not just the reason that justifies the original act of self-closure. Pursuing the maintenance of such correspondence must also be the constant grounding condition for citizenship. When I describe the correspondence between 'We, the Members' and 'We, the participants' as a constant condition, I do not want to deny that political communities need to undergo unavoidable changes in their distributive patterns. Quite the opposite. I want to illustrate how changes can undermine this correspondence and how a shift in the boundaries of political membership can be a solution for the problem of change.

The original correspondence between 'We, the Members' and 'We, the Participants' cannot be secured with the passing of time in the Walzerian model, precisely because Walzer argues that demands that come from the 'outside' cannot radically transform the outcome of the reflexive process which underpins the collective right of self-determination. But, are we sure that demands from individuals who are already taking part (even though not to a full extent) in the practices of distribution of rights and burdens, which keep alive the common life of a political community, are to be considered as coming from the outside? In other words, are we sure that those who hold formal political membership are the only ones to be included in the 'self' that is so pertinent to the process of self-determination?

Contrary to Walzer, I argue that there are limits to which the reflexive process of self-determination is subject. These limits derive from the fact that the self that is pertinent to the process of self-determination needs to be an expression of a common life that can never be entirely enclosed within the legal boundaries of formal political membership. ${ }^{72}$ As we have already seen, Walzer argues that those decisions that members take regarding their own membership, must lead back to a process of self-understanding of the existing community. I argue that political communities need to undergo the same reflexive process of self-understanding every time outsiders take root in the pattern of distribution to which the political community is committed. Decisions on the enjoyment of rights affect the self- 
understanding of a political community, just as decisions about membership do. To consider it to be the case that only those who hold formal membership have the capacity to influence the process of self-understanding of a political community would be reductive.

My alternative answer to the $\mathrm{C}^{\mathrm{Q}}$ holds that there is a collective point of view - the one that is tacitly in place in an indeterminate community of practices - that predates decisions on membership boundaries. Prior to the act of self-closure through which decisions about membership boundaries are taken, practices of exchange where an indeterminate collective point of view is at play are already taking place. ${ }^{73}$ This collective point of view at play in practices of exchange and distribution of social goods, where an indeterminate number of participants are involved, is usually mediated, but not necessarily exhausted, by the structure of formal political membership. Individuals involved in common practices of exchange of social goods can perceive a sort of unity that underpins their interaction, even when an actual counting of who is involved in such interaction has not yet occurred. With regard to a political community, the lack of formal political membership does not exclude that rights and obligations arise among the individuals who engage in practices of creation and exchange of social goods. That the parties involved are committed to carry on the exchange as part of a common enterprise is the sole condition for such obligations to arise.

Since an indeterminate collective point of view is already at play in practices of creation and exchange of social goods that predate the act of counting members, we can conclude that decisions that set membership boundaries do not have the function of bringing into existence the collective point of view that is necessary to take decisions on distribution. What decisions concerning membership boundaries then do is to perform an equalizing function among the ones who are jointly committed in practices of creation and exchange of social goods. From this perspective, the concept of self-determination has a quite different meaning: we do not decide how many we are, we decide that each of us must count as one in the distribution of burdens and social goods.

Whereas in the Walzerian model the right of collective self-determination was 'untameable' (in the sense that inputs from the outside were not capable of radically influencing a reflective process), in my model, the contestation against the membership structure does not come from the outside. This contestation is made possible by the provisional nature of the act of self-closure. This provisionality enables individuals who are already participants in the practices of exchange and distribution of social goods within a political community to claim that this distribution occurs also in their name. In other words, the shift of membership boundaries, in borderline cases such as Zambrano, is not a shift that allows people on the 'outside' to be admitted within a political community. It is rather a shift that

73 Here, I am referring to the account of joint commitment as a source of obligations proposed by Margaret Gilbert. See especially Part 2 on 'Societies, Membership and Obligation,' in Margaret Gilbert, A Theory of Political Obligation (Oxford: Oxford University Press, 2006), 91-182. 
secures to all the participants in the practices of exchange and distribution of social goods that hold a political community together to be counted in on an equal basis.

\subsection{The indeterminacy of the pool of participants in practices of exchange of social goods}

In the previous sections, I have argued that the function of citizenship is securing the correspondence over time between the circle of members of a political community and the pool of participants in the exchange of social goods. I will now clarify how this correspondence is always a moving target rather than a definitive achievement. This is because each renewal of the act of self-closure, including the initial one, lacks the capacity to eliminate the indeterminacy of the pool of participants in the distributive practices that occur with reference to the political community.

This mechanism of back and forth from the $\mathrm{M}^{\mathrm{Q}}$ to the $\mathrm{D}^{\mathrm{Q}}$ sits well with the two arrows representing my own answer to the $\mathrm{C}^{\mathrm{Q}}$. The distribution of social goods requires membership boundaries to be in place. At the same time, practices of exchange of social goods are what shape and sustain membership boundaries. However, it is impossible to simultaneously place decisions concerning the membership boundaries of a political community and the practices of exchange of social goods that concern this political community into focus. The two arrows in my account of the $C^{\mathrm{Q}}$ represent this impossibility and propose an oscillation of focus - from the $\mathrm{M}^{\mathrm{Q}}$ to the $\mathrm{D}^{\mathrm{Q}}$, and vice versa - in order to get a better understanding of the function of citizenship.

The reason why it is not possible to place both decisions on membership boundaries and practices of exchange of social goods into focus at the same time, is because decisions on membership boundaries always need a reflective moment whereby someone from the group of members refers to the group as a 'we' acting together. Therefore, there cannot be decisions on membership boundaries without the necessary mediation of representation. Practices of exchange of social goods take place, instead, in a continuum of social interactions where the 'acting together' is not always backed up by a reflexive moment. Let me introduce a practical example to clarify this point.

East-point Tower is a huge residential building with nearly 350 residents. A communal park named Nymphae Garden surrounds the building. In the last years, the residents of the East-point Tower have been organizing a yearly get-together event known as the East-point Summer Barbeque. The BBQ takes place in the Nymphae Garden every 21st of June. When the BBQ initiative was launched only a small group of residents participated. However, year by year, the number of participants has grown so much that an organizing committee has been set up. The creation of this committee was sponsored by a 'call to action' letter that was left in the mailboxes of all the residential units. The letter invited all those who would be interested in volunteering for the organization of the BBQ to meet on the third Sunday of May at 11:00 in Apartment $\mathrm{N}^{\circ} 22$. 
At this first meeting, a few of the residents showed up and the organizing committee was constituted. As a first step, the organizers agreed to open the registration for the BBQ and to collect the participation fees. The registration was necessary to count the participants and to arrange the catering service for the party accordingly. To easily reach the largest number of participants, the organizers decided to leave the following letter in the mailboxes of all the residential units:

Dear East-point People,

The East-point Summer BBQ will be held on June 21st in Nymphae Garden. The participation fee is 15 EUR. You are kindly requested to confirm your participation via e-mail. Please, indicate the number of participants \& guests (two guests are allowed for each residential unit).

The strategy of the invitation was a success! In the first week, many participants had already registered. However, the organizing committee decided to set up a second, urgent, meeting, to discuss the following atypical requests of registration: a The registration letter clearly stated that only two additional guests are allowed for each residential unit. However, in two cases, the number of people registered as participants differs from the number of residents officially registered at the municipality. In one case, the participant who does not result in the official register is the partner of a young lady. This gentleman had just recently moved into her apartment. This couple invited another couple of friends to the BBQ (so their registration counts already two guests). In the second case, the participant who does not result in the official register is an in-home nurse who takes care of an old lady who has difficulties in moving autonomously. The old lady has also invited her two sons as guests. Shall the organizing committee contact the old lady and the young lady and decline the registration of the sons and of the other couple, respectively, since only two additional guests are allowed for each residential unit?

b The organizers have noticed that in five cases residents have registered more than two guests, and paid accordingly for the BBQ. Shall the organizing committee contact these residents and decline the registration of their extra guests?

The organizers agreed that they had to be cautious in dealing with these atypical requests in order to not leave someone feeling excluded from a party, which was supposed to celebrate the communal life in East-point Tower. It was decided that registrations will be declined in case (b). That is because the residents who invited extra guests are clearly going against the common rules set in the letter of invitation. The Summer BBQ is not their own private party, so they cannot invite as many people as they want. The BBQ is an event organized for East-point people, and the limits to the number of guests that can be admitted are justified since the Nymphae Garden is a limited space.

The case of the partner, who had recently moved in the East-point Tower, and the case of the in-home nurse, ignited a heated debate amongst the organizers. Even though there was a general consensus about the fact that these individuals cannot be excluded from the party, there was disagreement on whether they have to be 
admitted to the BBQ as participants or as guests. Indeed, accepting the in-home nurse and the partner as participants means that the old lady and the young lady can still bring the two sons and extra guests to the BBQ. The opponents of this view argued that this case would constitute a breach of the general rule of maximum two guests for each residential unit. The ones who claimed instead that the not-registered partner and the in-home nurse ought to be accepted as participants appealed to the fact that these people are no longer mere guests in the residential units where they have settled. Therefore, the East-point Summer Party is to be considered their party too.

During the whole year, the residents of the East-point Tower interact on a daily basis. They pay their rents and taxes, place their waste containers outside, walk their dogs in the Nymphae Garden, greet each other on the stairs and some even have disputes with their neighbours that have been going on for years. In other words, they act together and interact with each other, and still they are not moved by the daily necessity to refer to themselves as 'the East-point people.' They are, so to speak, the ones that in my account of the $C^{Q}$, I indicate as the 'Participants.' However, at least once a year, a reflexive moment is necessary for the East-point people. This happens when it is time to arrange the Summer BBQ. Then, a shift occurs from the indeterminacy of the group of people living in Eastpoint Tower, to the determination of the number of participants in the Summer $\mathrm{BBQ}$. In the story, the organizing committee voices a rudimental form of representation of the East-point people and is in charge of regulating the registration to the party (so as, in the case of political communities, formal members are in charge of deciding about membership boundaries). The atypical requests in case (a) are instances of what I earlier referred to as mismatches between the circle of members and the pool of participants.

In order to examine the impossibility of putting both the circle of members and the pool of participants into focus at the same time, I propose to have a closer look at the borderline case of the young lady living with the non-registered partner. When the young lady asked her lover to move in with her in her apartment at the East-point Tower, we can easily suppose that the first thought in the gentleman's mind was not: 'Now, I am finally a member of the East-point people and I can join the BBQ party!' This example shows that all interactions that provide grounds to the recognition of someone as a participant into the East-point communal life do not occur with the East-point people as a firm reference point. Similar considerations can be drawn with regard to the reverse perspective: when the organizers decided to leave the invitation to the $\mathrm{BBQ}$ in all the mailboxes located in the East-point Tower, no one was really paying attention to the web of actions and interactions that unfold daily within the four walls of each residential unit or along the paths of the Nymphae Garden. We can say that East-point is an ambiguous picture with two faces that cannot be grasped at once. On the one hand, individuals involved in the daily interaction are focused on their interpersonal relations, whilst the idea of a 'We' acting together stays only in the background. On the other hand, when it is time to organize the Summer BBQ, the question 'who 
are the people of East-point?' becomes more urgent. Then, the volunteers of the organizing committee who need to send the invitations cannot have a comprehensive picture of the individual stories behind the doors of each residential unit of East-point.

However, in order to ensure the success of the BBQ party, it is necessary that the perspective of the organizers is as congruent as possible with that of the individuals who participate in the daily life of East-point. Therefore, to go on with the comparison, the party will be successful if those who are in charge of its organization are able to re-adjust their perspective on 'who is part of the people of Eastpoint' every time that they intercept a signal of mismatch - an unexpected registration that they cannot decline, for example - which reveals that individuals, who were already embedded in communal life through actions and interaction, have been previously miscounted in the perspective of the organizers.

To conclude, the practices of exchange of social goods that occur with reference to a political community do not only reaffirm the dividing line between members and non-members, as drawn in the initial act of self-closure. Through interactions, participants in the exchange of social goods can develop and attune their mutual expectations without the necessity of constantly engaging in a reflexive operation. Therefore, it is the very interaction among participants in practices of the exchange of social goods that forms the background of a pre-reflexive normativity that, at a later stage, allows participants to refer to themselves as a 'we' acting together when decisions on membership boundaries and distribution are taken.

\section{Conclusion}

The analysis takes as its starting point a new jurisdictional test on EU citizenship rights launched in 2011: the Zambrano formula. The Zambrano formula applies to threshold situations where granting residence rights to third country national parents is the only way to protect the rights of their minor children, who are EU citizens. To express this idea, the Court of Justice refers to the substance of rights. Taking cue from this reference to substance of rights, I have drawn attention to the relational and intersubjective dimension that is distinctive of citizenship rights. Each right is part of a more complex pattern of the distribution of social goods, and such distribution is what holds a political community together.

I have proposed to adopt a two-pronged approach to deal with questions concerning citizenship. This is because, on the one hand, citizenship is linked with the issue of distribution; while, on the other, it is linked to the issue concerning membership boundaries. I have argued that the function of citizenship is to secure the convergence between decisions about distribution and decisions about political membership. I concluded by arguing that changes in the pool of participants in the practices of creation and exchange of social goods to which a political com- 
munity is committed have the potential to reshape the membership boundaries of such a community. 